\title{
Manajemen Berbasis Sekolah sebagai Landasan Kepala Sekolah dalam Peningkatan Mutu Pendidikan Agama Islam
}

\author{
Zulfikar Yusuf \\ Fakultas Agama Islam Universitas Muhammadiyah Malang \\ zulfikar_yusuf@umm.ac.id \\ Dina Mardiana \\ Fakultas Agama Islam Universitas Muhammadiyah Malang \\ dinamardiana@umm.ac.id
}

Naskah diterima: 30 November 2019| Naskah disetujui: 11 April 2020

\begin{abstract}
As a management concept in the field of education management, School Based Management (SBM) was born in the midst of an era of freedom that has emerged since 2004. Through a central government policy that gives flexibility to each education unit in the region to manage their respective institutions. The aims of this article is to analyze: 1) Philosophical foundation of School Based Management (MBS) implementation at SMP Muhammadiyah 4 Malang, 2) The role of school headmaster in improving the quality of Islamic Education at Muhammadiyah 4 SMP Malang. Therefore, this research uses a qualitative approach to the type of case study research. By using observations, interviews and documentation as data collection techniques, this study concludes namely: 1) The philosophical foundation of policy implementation in SMP Muhammadiyah 4 Malang refers to the vision and mission announced by the school, 2) The headmaster of SMP Muhammadiyah 4 Malang has carried out a managerial process well. However, at the evaluation stage there are a number of activities that have not been carried out properly, so that it is unable to locate the shortcomings in the process of the activities carried out.
\end{abstract}

Keywords: Leadership, School Based Management, Islamic Education, School Headmaster

\begin{abstract}
Abstrak
Sebagai sebuah konsep manajemen di bidang pengelolaan pendidikan, Manajemen Berbasis Sekolah (MBS) lahir di tengah-tengah era kebebasan yang telah mengemuka sejak tahun 2004 silam. Melalui kebijakan pemerintah pusat yang memberi keleluasaan pada tiap satuan pendidikan di daerah untuk mengelola lembaganya masing-masing. Tujuan penulisan artikel ini ialah untuk menganalisis: 1) Landasan filosofis implementasi Manajemen Berbasis Sekolah (MBS) di SMP Muhammadiyah 4 Malang, 2) Peran kepala sekolah dalam meningkatkan mutu Pendidikan Agama Islam di SMP Muhammadiyah 4 Malang. Oleh karenanya, riset ini menggunakan pendekatan kualitatif dengan jenis penelitian studi kasus. Dengan menggunakan observasi, wawancara dan dokumentasi sebagai teknik pengumpulan data, penelitian ini berkesimpulan antara lain: 1) Landasan filosofis implementasi kebijakan di SMP Muhammadiyah 4 Malang mengacu pada visi misi yang dicanangkan oleh sekolah, 2) Kepala SMP Muhammadiyah 4 Malang telah melakukan proses manajerial dengan baik. Namun, pada tahapan evaluation terdapat beberapa aktivitas yang belum dilakukan proses evaluasi dengan baik, sehingga tidak mampu menemukan letak kekurangan dalam proses kegiatan yang dilakukan.
\end{abstract}


Kata Kunci: Kepemimpinan, Manajemen Berbasis Sekolah (MBS), Pendidikan Agama Islam, Kepala Sekolah

\section{Pendahuluan}

Dalam sebuah lembaga pendidikan, kepala sekolah berperan sebagai faktor kunci penentu kualitas pendidikan pada satuan pendidikan yang dipimpinnya (Ekosiswoyo 2007), baik pada lembaga pendidikan formal keagamaan yang berbentuk madrasah (Asmiyati 2018) maupun sekolah formal yang berafiliasi pada Kementerian Pendidikan (Rahayuningsih, R., \& Rus 2013). Hal tersebut nyatanya merupakan sebuah fakta riil karena kepala sekolah memiliki wewenang mutlak dalam mengambil kebijakan untuk kemajuan institusi yang diembannya. Melalui pendidikan serta proses manajemen yang tepat (Fachruddin 2009), termasuk pola kepemimpinan dan supervisi yang baik (Mubin 2006), maka target pencapaian tujuan pembelajaranpun akan dapat tercapai dengan baik pula.

Pada lini yang lain, urgensitas peran kepala sekolah dalam melakukan proses manajerialnya, tidak dapat seutuhnya terlepas dari basis manajemen yang digunakan dalam mengatur sistem pendidikan di tingkat kelembagaan. Di antara basis tersebut, terdapat sebuah acuan yang disebut dengan Manajemen Berbasis Sekolah (MBS) sebagai sebuah konsep pengelolaan pembelajaran pada tingkat satuan pendidikan. Alih-alih sebagai sebuah konsep parsial, Manajemen Berbasis Sekolah mempunyai cakupan yang cukup general, mulai pada aspek teoritis-normatif hingga pada sisi praksis-implementatif. Dengan demikian, pemahaman yang sifatnya komprehensif tentang landasan filosofis Manajemen Berbasis Sekolah mutlak dimiliki oleh seorang kepala sekolah sebagai salah satu opsi konsetuan dalam melaksanakan tugas manajerial di satuan pendidikan yang menjadi wilayah tanggungjawabnya.

Namun, tataran idealis tersebut tidak sepenuhnya nampak di SMP Muhammadiyah 4 Malang. Data statistik pihak internal sekolah tersebut mencatat, terjadi deviasi jumlah peserta didik semenjak tiga tahun terakhir ini. Dengan 180 peserta didik pada tahun ajaran 2016/2017, menurun hingga 11 persen menjadi 160 peserta didik, dan pada tahun ajaran berikutnya yakni 2018/2019 berkurang kembali menjadi 150 peserta didik (Maiyam 2019).

Menilik pada data, maka analisa terkait fenomena penurunan jumlah peserta didik tersebut menjadi sebuah poin yang perlu untuk diungkap. Jika melihat pada urgensitas peran kepala sekolah dan konsep Manajemen Berbasis Sekolah (MBS) pada deskripsi sebelumnya, maka lazim apabila riset yang penulis lakukan ini mengacu pada dua fokus permasalahan: pertama, Apa landasan filosofis implementasi Manajemen Berbasis Sekolah (MBS) di SMP Muhammadiyah 4 Malang? dan kedua: Bagaimana peran kepala sekolah dalam meningkatkan mutu Pendidikan Agama Islam di SMP Muhammadiyah 4 Malang?

Melalui fokus permasalahan tersebut, maka penelitian ini menggunakan pendekatan kualitatif dengan jenis penelitian studi kasus. Melalui observasi, wawancara dan dokumentasi sebagai teknik pengumpulan data, selanjutnya data diolah dengan berdasar pada konsep Miles dan Hubermann. Sebagai langkah berikutnya maka triangulasi dipilih sebagai uji validitas dari data yang ada. 


\section{Manajemen Berbasis Sekolah: Landasan filosofis-interpretatif}

Sebagai sebuah konsep manajemen di bidang pengelolaan pendidikan, Manajemen Berbasis Sekolah (MBS) lahir di tengah-tengah era kebebasan -baca: otonomi- daerah yang telah mengemuka sejak tahun 2004 silam. Melalui kebijakan pemerintah pusat yang memberi keleluasaan pada tiap satuan pendidikan di daerah untuk mengelola lembaganya masing-masing. Manajemen Berbasis Sekolah (MBS) menjadi salah satu pilihan bagi kepala sekolah dalam melakukan tugas manajerialnya.

Pemahaman mendalam tentang aspek filosofis yang mendasari penerapan Manajemen Berbasis Sekolah (MBS), perlu dimiliki oleh tiap pemangku kebijakan tertinggi di tingkat satuan pendidikan -baca: sekolah- yang tidak lain berada di tangan kepala sekolah. Dengan memiliki pemahaman secara gradual dan komprehensif, akan berimplikasi pada ketepatan, keefektifan dan keefisienan tiap kebijakan yang dikeluarkan dalam ranah proses pembelajaran di sekolah.

Oleh karenanya, keberhasilan sebuah pendidikan dapat dicanangkan sejak awal. Hal tersebut mengindikasikan bahwa perspektif filsafat melalui kajian filosofisnya, akan mampu mendorong terwujudnya pendidikan yang diinginkan, sebagaimana argumen yang diungkap oleh Bourne (Bourne, Crossfield, and Nicholas 2017). Melalui kajian filosofis yang tepat, maka sisi epistemologis dalam hal teknis penerapan di lapangan akan dapat diarahkan dengan lebih baik.

Dalam tataran implementatifnya, riset yang mengetengahkan tema Manajemen Berbasis Sekolah (MBS) telah dilakukan oleh beberapa peneliti sebelumnya. Seperti Triyanto misalnya, yang mengungkapkan peran penting kepala sekolah dalam pemberdayaan media pembelajaran yang dimiliki oleh satuan pendidikan yang dinaunginya, guna meningkatkan kualitas proses pembelajaran yang berlangsung (Triyanto, Anitah, and Suryani 2013). Artinya bahwa, pengelolaan media pembelajaran secara efektif dan efisien pun merupakan tangguungjawab dari kepala sekolah yang secara regulasi formalitasnya dapat dilakukan melalui otonomi pendidikan yang ada pada satuan pendidikan masing-masing.

Riset lain mengungkapkan bahwa konsep Manajemen Berbasis Sekolah (MBS) yang dilakukan di Indonesia, merupakan sebuah konsep yang dapat disesuaikan dan diadaptasikan dengan situasi kondisi - khususnya pada bidang pendidikan- yang ada di negara Indonesia. Melalui pola pengadaptasian tersebut, diharapkan akan mampu meningkatkan kualitas setiap aktivitas maupun program yang ada pada masing-masing satuan pendidikan (Nurabdiah 2016).

Secara filosofis, riset tersebut mengungkap linearitas penerapan Manajemen Berbasis Sekolah (MBS) antara aspek praksis-implementatifnya dengan konsep teoritis-normatifnya. Artinya, kewenangan yang dimiliki oleh satuan pendidikan dalam mengadaptasikan konsep Manajemen Berbasis Sekolah (MBS) telah mengacu dan sesuai dengan landasan filosofis pendidikan yang menginginkan tercapainya manusia paripurna yang memiliki keseimbangan kemampuan baik secara kognitif, afektif, maupun psikomotorik.

Melalui Manajemen Berbasis Sekolah (MBS), masing-masing satuan pendidikan mempunyai otoritas dalam mengambil kebijakan akademik (Zaini 2015) baik melalui pelibatan pihak internal maupun pihak eksternal sekolah. Pihak internal merujuk pada pendidik, peserta didik dan tenaga kependidikan. Sedangkan pihak eksternal yang dimaksud ialah stakeholder yang berelasi dengan pihak sekolah (Purnama 2019) seperti orangtua/ wali peserta didik dan komite sekolah. Dengan 
melibatkan dua unsur tersebut, maka Manajemen Berbasis Sekolah (MBS) secara filosofis akan mampu mendorong tercapainya tujuan pembelajaran dengan terarah.

Landasan filosofis konsep Manajemen Berbasis Sekolah (MBS) dalam dimensi yang lain juga mampu mengoptimalkan tugas manajerial yang diemban oleh kepala sekolah pada masing-masing satuan pendidikan. Secara teoritis, fungsi manajerial yang harus diemban oleh kepala sekolah meliputi tugas sebagai pemimpin (leader), pendidik (educator), pengatur (administrator), pembaharu (innovator), pengawas (supervisor), hingga pada fungsi sebagai pendorong (motivator) (Mulyasa 2011). Lazim apabila melalui konsep tersebut, dapat ditarik sebuah simpulan mengenai indikator dari Manajemen Berbasis Sekolah (MBS) sebagaimana riset yang menyimpulkan adanya tiga indikator dalam meneropong Manajemen Berbasis Sekolah (MBS) tersebut, yakni pada input pendidikannya berasal dari sumber daya yang kompeten, proses pendidikan yang dilakukan memiliki tingkat efektifitas yang tinggi, serta yang ketiga ialah pada output pendidikan yang berkualitas (Dolong 2018).

Beberapa deskripsi tersebut, mengantarkan pada analisa terkait landasan filosofis yang dilaksanakan di lokus penelitian ini yakni SMP Muhammadiyah 4 Malang. Berdasar pada observasi serta interview yang penulis lakukan, diperoleh gambaran bahwa secara filosofis, konsep manajerial yang digunakan oleh pihak sekolah telah mengacu pada Manajemen Berbasis Sekolah (MBS) dan tertuang melalui visi misi SMP Muhammadiyah 4 Malang. Target jangka panjang -baca: visi- di sekolah tersebut telah menyatakan target menujudkan peserta didik yang bertaqwa dan berakhlakul karimah. Hal tersebut mewujud secara lebih spesifik melalui misi sekolah dan kebijakan akademis yang dilakukan oleh kepala sekolah.

\section{Peran Kepala Sekolah dalam Pengembangan Mutu PAI}

Sebagaimana uraian sebelumnya, dalam scope pengelolaan pendidikan pada satuan pendidikan, kepala sekolah memegang peranan pokok dalam mengemban tugasnya sebagai leader, educator, administrator, innovator, supervisor hingga pada fungsi sebagai motivator. Dalam riset ini, terdapat beberapa temuan terkait fungsi manajerial kepala SMP Muhammadiyah 4 Malang, di antaranya ialah:

Pertama, aspek perencanaan (planning). Pada tahap ini, kepala sekolah berkoordinasi dengan para staf dan tenaga kependidikan yang ada di SMP Muhammadiyah 4 Malang, termasuk pada saat koordinasi tersebut, kepala sekolah mengajak serta guru mata pelajaran Pendidikan Agama Islam (PAI) guna melakukan penyamaan tujuan pembelajaran yang hendak dilakukan pada setiap semesternya.

Peningkatan mutu PAI yang ada di SMP Muhammadiyah 4 Malang tidak hanya menjadi tanggung jawab guru pengampu mata pelajaran tersebut, akan tetapi juga berada di bawah koordinasi, pengawasan, sekaligus tanggung jawab kepala sekolah SMP Muhammadiyah 4 Malang. Hal tersebut terbukti dari hasil petikan wawancara berikut:

"Saya percaya bahwa tugas mendidik AIK bukan hanya guru PAI, namun juga guru yang lain. maka semua kegitan keagamaan mengikutsertakan guru mapel lain. hal tersebut dilakukan untuk memberikan contoh yang baik kepada para peserta didik. Program yang kami buat lebih banyak diarahkan untuk peserta didik, namun ada pula beberapa program yang dibuat untuk para guru. karena kegiatan keagaman di sini 
juga mengikutsertakan para guru dalam mengawasi maupun mendampingi. Kalau meraka mendampingi hafalan al-Qur'an, maka guru yang mendampingi perlu memiliki kemampuan, jangan sampai yang menilai kemampuan membaca al-Qur'an masih kurang, maka ada juga kegiatan untuk para guru"(Thoyib 2019)

Sebagai langkah nyata peran kepala SMP Muhammadiyah 4 Malang, terdapat upaya penguatan bagi para pendidik SMP Muhammadiyah 4 Malang dalam hal pengetahuan dan keterampilan melalui beberapa pelatihan yang melibatkan pendidik secara langsung. Pelatihan yang secara kontinyu diikuti oleh para pendidik di sekolah tersebut, diharapkan mampu memberikan implikasi dan dampak positif bagi perkembangan lembaga pendidikan.

Upaya kepala SMP Muhammadiyah 4 Malang tersebut, ternyata belum mampu meningkatkan respon masyarakat untuk menyekolahkan putra/putrinya di lembaga pendidikan tersebut. Dari data sekolah, diperoleh informasi bahwa peserta didik yang menimba ilmu di lembaga pendidikan ini berasal dari kalangan masyarakat dengan tingkat perekonomian menengah ke bawah. Fakta yang demikian mengarahkan kepala SMP Muhammadiyah 4 Malang untuk mengemas program-program pendidikan dengan sebaik mungkin, meskipun secara kuantitas belum mampu menaikkan jumlah peserta didiknya selama tiga tahun terakhir ini, sebagaimana penjelasan berikut:

"Siswa di sini semakin menurun, banyak yang memilih sekolah di tempat lain. kadang ada juga anak yang sudah tidak diterima di sekolah lain dan menjadikan sekolah ini pilihan terakhir. Walaupun ada juga beberapa siswa yang sejak awal memilih untuk bersekolah dan menuntut ilmu di sekolah ini. Input kita tidak banyak yang bagus, tapi kami berusaha untuk memberikan yang terbaik" (Thoyib 2019).

Secara riil, terdapat beberapa agenda kegiatan yang dilaksanakan oleh pihak sekolah, di antaranya ialah pelaksanaan salat dhuha dan salat dzuhur berjamaah yang kemudian dilanjutkan dengan materi Kuliah Tujuh Menit (kultum). Selain itu, keaktifan peserta didikpun sebenarnya mulai diasah dan dibiasakan oleh pihak SMP Muhammadiyah 4 Malang melalui gilir petugas azan dan ikamah pada setiap salat berjamaah, program menghafal ayat al-Qur'an, keputrian, serta adanya program Darul Arqom. Untuk para pendidik, SMP Muhammadiyah 4 Malang mengadakan program tahsin, pembinaan AIK dari PCM, serta mendelegasikan beberapa pendidik untuk mengikuti kegiatan pelatihan di luar sekolah. Dari seluruh kegiatan yang terjadwal tersebut, terdapat juga kegiatan yang bersifat insidental seperti misalnya kegiatan pendukung yang didapat dari kerjasama dengan pihak lain. Hal tersebut terungkap dari hasil wawancara penulis dengan kepala sekolah berikut:

"Kegiatan yang dilakukan di sini banyak mas, diawali dari salat dhuha, salat dzuhur berjamaah, waktu salat dzuhur siswa laki-laki dijadwal menjadi muadzin dan ikamah, setelah salat dzuhur ada kultum dan hafalan, kalau hari jum'at ada keputrian dan setahun sekali ada Darul Arqom".

"Kalau untuk guru, kami lakukan belajar tahsin seminggu sekali, ada pembinaan dari PCM, dan kadang diutus untuk mengikuti kegiatan-kegiatan yang mendukung jurusannya" (Thoyib 2019). 
Kedua, aspek pelaksanaan dan pengawasan (actuating andcontrolling). Dalam aspek ini, kepala sekolah menjalankan perannya sebagai penanggungjawab penuh terhadap segala aktivitas atau kegiatan yang dilaksanakan di lembaga pendidikan, baik berupa aktivitas keagamaan maupun kegiatan yang sifatnya umum. Berbagai kegiatan keagamaan dilakukan di sekolah sebagaimana narasi deskriptif sebelumnya.

Setiap kegiatan yang dilaksanakan selalu menginformasi kepada kepala sekolah, sehingga kepala sekolah selalu mengetahui kegiatan-kegiatan yang dilaksanakan di sekolah oleh para pendidik, baik kegiatan tersebut diadakan secara kontinyu dan berkala, maupun kegiatan insidental yang sifatnya non-rutin. Jika kemudian terdapat instansi eksternal yang ingin mengadakan kegiatan apapun di SMP Muhammadiyah 4 Malang, para guru selalu mengarahkan untuk bertemu langsung dengan kepala sekolah. Hal ini menunjukkan bahwa kepala sekolah menjadi sentral pengambil kebijakan setiap kegiatan yang dilaksanakan di sekolah.

Dalam pembagian tugas para guru, kepala sekolah melakukan tugas controllingnya melalui pengamatan dan pengenalan langsung kepada tiap guru. Pendidik yang memiliki kemampuan dalam bidang keagamaan diberikan kepercayaan untuk mendapingi maupun menjadi tutor peserta didik. Terdapat pendidik yang memiliki kemampuan dalam tartil, pendidik tersebut diberikan kepercayaan untuk mendampingi ekstra kurikuler MTQ. Adapun mayoritas guru yang lain diberikan kepercayaan untuk mendampingi hafalan al-Qur'an peserta didik.

"Penanggungjawab kegiatan keagamaan adalah Pak Arifin dan Bu Anik, namun guruguru juga diminta membantu pelaksanaan kegiatan tersebut. Mendampingi dan kadang menjadi imam salat. Semua guru juga diberikan tanggunjawab untuk mendampingi peserta didik dalam hafalan" (Thoyib 2019).

Untuk aktivitas keputrian dilaksanakan di masjid sekolah dan di ruang kelas. Masjid merupakan tempat yang efektif dalam menjalankan kegiatan-kegiatan. Seluruh siswa mampu ditampung di masjid yang ukurannya cukup besar untuk 100-200 jamaah. Beberapa kegiatan dilaksanakan secara bersama dan beberapa yang lainnya dilaksanakan secara kelompok.

Adapun kegiatan keagamaan untuk para guru, kepala sekolah berusaha selalu hadir dan ikut serta dalam kegiatan yang dilaksanakan. Kegiatan-kegiatan itu bukan hanya sekedar dilaksanakan untuk memberikan pengetahuan, namun juga sarana keakraban dan pengenalan antara pendidik bahkan bersama keluarga yang dibawa.

"Untuk kegiatan guru, diadakan pelatihan tahsin. Para guru diminta untuk mendampingi dan mengawasi bacaan peserta didik, maka para guru harus dilatih agar memiliki kemampuan untuk mendampingi dengan baik. Untuk kegiatan kajian rutin bulanan dilaksanakan dengan bekerjasama dengan PCM, kita mengkonsep materinya dan pemateri dari PCM, kadang juga menghadirkan dari PDM” (Thoyib 2019).

Beberapa kegiatan yang sifatnya melatih berdampak langsung kepada para peserta didik, yang awalnya tidak terbiasa menyampaikan materi di depan umum, maka dengan adanya program tersebut peserta didik mampu merasakan dan belajar dari proses yang dialaminya. Pada kegiatan hafalan Qur'an, para siswa diberikan reward berupa penghargaan kepada peserta didik yang dapat 
menghafalkan juz 30. Penghargaan berupa pembebasan SPP beberapa bulan dan mendapatkan hadiah berupa al-Qur'an hafalan.

"Untuk memberikan semangat kepada para siswa, kami memberikan penghargaan kepada para siswa yang mampu menghafal juz 30 dan yang lebih. Beberapa tahun lalu, tiga siswa kami dapat menghafal juz 29 dan 28. Namun, tahun ini tidak ada yang mencapai target" (Thoyib 2019).

Sebagai penanggungjawab pada setiap kegiatan yang dilaksanakan oleh pendidik, kepala sekolah hadir untuk melakukan pengawasan dan pengamatan. Pengawasan dan pengamatan tersebut dilakukan untuk memberikan contoh dan membangun kesetaraan antara para pendidik.

Rapat selalu dilakukan untuk mengetahui progress setiap kegiatan. Pelaksanaan rapat dengan guru-guru tidak selalu terjadwal, namun bersama staf (seluruh wakil kepala sekolah) selalu melaksanakan rapat seminggu sekali. Rapat dilaksanakan untuk membahas kegiatan yang dilaksanakan.

"Kalau rapat bersama staf itu rutin dilaksankan seminggu sekali, kalau rapat dengan guru-guru dilaksanakan sesuai kebutuhan, jadi tidak rutin. Rapat yang diadakan untuk membahas program sekolah yang sudah dilaksanakan dan segala hal yang menjadi kendala"(Thoyib 2019).

Ketiga, evaluasi. Pada tahapan ini, kepala sekolah melakukan beberapa aktivitas untuk mendapatkan evaluasi. Tinjauan evaluasi yang dilakukan adalah tinjauan efektifitas dan efisiensi kegiatan. Setiap kegiatan yang dilakukan selalu membuat laporan dan ditandatangani kepala sekolah. Ketika pelaporan dilakukan, maka kepala sekolah mampu mengecek hasil dari setiap kegiatan. Beberapa berkas laporan diletakkan di lemari kantor, beberapa yang lainnya disimpan oleh kepala sekolah.

Hal tersebut mengindikasikan bahwa sistem pelaporan telah dilakukan dengan baik, seluruh berkas dimiliki untuk dijadikan laporan setiap semester. Namun, terdapat beberapa kegiatan yang tidak dilakukan proses evaluasi yang baik. Kegiatan pengembangan PAI untuk para pendidik dilaksankan dengan baik, namun berkas progress kemampuan belum disediakan, hanya pengakuan dari beberapa pendidik.

\section{Kesimpulan}

Berdasar pada dekripsi pembahasan penelitian, diperoleh kesimpulan bahwa diantara indikator kompetensi seorang leader of education terletak pada kemampuan melakukan tugas pengelolaan dengan baik. Hal tersebut seharusnya diiringi dengan pemahaman komprehensif terkait landasan filosofis yang menjadi acuan setiap kebijakan akademik yang diputuskan oleh kepala sekolah. Di SMP Muhammadiyah 4 Malang, kepala sekolah telah melakukan proses manajerial dengan baik. Namun, pada proses evaluasi terdapat beberapa aktivitas yang belum dilakukan proses evaluasi dengan baik, sehingga tidak mampu menemukan letak kekurangan dalam proses kegiatan yang dilakukan.

Peran kepala SMP Muhammadiyah 4 Malang pada aspek perencanaan telah melakukan pemetaan kemampuan dan pembagian tanggungjawab kepada tenaga pendidik yang ada di sekolah tersebut. Kepala sekolah melakukan koordinasi dengan tenaga pendidik maupun wakil kepala 
sekolah dalam menentukan dan mengawasi proses kegiatan yang dilakukan. Setiap kegiatan yang diadakan harus melalui persetujuan kepala sekolah, begitu pula setelah kegiatan dibuatkan laporan akhir setiap semester dan dilaporkan kepada kepala sekolah. Pada aspek administrasi evaluasi dijalani dengan baik, namun pada aspek taknis, belum ditemukan sehingga perlu dilakukan ketelitian dalam menentukan indikator dalam pelaksanaan.

\section{Daftar Pustaka}

Asmiyati. (2018). "Model Kepemimpinan Kepala Madrasah Dalam Meningkatkan Mutu Sumber Daya Di Madrasah Ibtidaiyah Ma ' Arif Giriliyo I Wukirsari Imogiri Bantul.” Jurnal Pendidikan Madrasah 3(1):41-54.

Bourne, Paul Andrew, Devon Crossfield, and Vivian Nicholas. (2017). "Contemporary Theories of Education and Analytic Philosophy of Education." International Journal of Transformation in English \& Education 2(2):1-5.

Dolong, J. (2018). "Karakteristik Manajemen Pendidikan Berbasis Sekolah.” Jurnal Inspiratif Pendidikan 7(1):1-10.

Ekosiswoyo, R. (2007). “Kepemimpinan Kepala Sekolah Yang Efektif Kunci Pencapaian Kualitas Pendidikan.” Jurnal Ilmu Pendidikan 14(2):76-82.

Fachruddin. (2009). "Manajemen Pemberdayaan Dalam Peningkatan Mutu Pendidikan Islam Di Indonesia." Ta'dib 12(1):49-56.

Maiyam, D. (2019). Rekap Jumlah Peserta Didik SMP Muhammadiyah 4 Malang. Malang.

Mubin, A. (2006). "PENINGKATAN KUALITAS PENDIDIKAN ( Perspektif Manajemen Pendidikan Islam )." Jurnal Hunafa 3(4):351-64.

Mulyasa, E. (2011). Menjadi Kepala Sekolah Profesional. Jakarta: Grasindo.

Nurabdiah, S. (2016). "Manajemen Berbasis Sekolah Dalam Meningkatkan Kualitas Sekolah." Jurnal EduTech 2(1):86-96.

Purnama, M. (2019). Implementasi Pendidikan Agama Islam yang Integratif (Antara Guru, Orang Tua, dan Masyarakat). QALAMUNA: Jurnal Pendidikan, Sosial, Dan Agama, 11(2), 141-156. https://doi.org/10.5281/zenodo.3559273

Rahayuningsih, R., \& Rus, P. (2013). “Kepemimpinan Kepala Sekolah Dalam Pembelajaran (Studi Kasus Sekolah Dasar Negeri Wonosari." Universitas Muhammadiyah Surakarta.

Thoyib. (2019)."Koordinasi Mata Pelajaran PAI."

Triyanto, E., Sri Anitah, and Nunuk Suryani. (2013). "Peran Kepemimpinan Kepala Sekolah Dalam Pemanfaatan Media Pembelajaran Sebagai Upaya Peningkatan Kualitas Proses Pembelajaran.” Jurnal Teknologi Pendidikan 1(2):226-38.

Zaini, A. (2015). "Manajemen Berbasis Sekolah: Alternatif Peningkatan Mutu Peningkatan Madrasah.” Jurnal EL-Tarbawi 8(1):69-92. 